Additional Perspectives articles for Influenza: The Cutting Edge book collection are available at http://perspectivesinmedicine.cshlp.org/cgi/collection/influenza_the_cutting_edge.

\title{
Equine Influenza
}

\author{
Thomas M. Chambers \\ Department of Veterinary Science, Maxwell H. Gluck Equine Research Center, University of Kentucky, \\ Lexington, Kentucky 40546, USA \\ Correspondence: tmcham1@uky.edu
}

Horses are the third major mammalian species, along with humans and swine, long known to be subject to acute upper respiratory disease from influenza A virus infection. The viruses responsible are subtype $\mathrm{H} 7 \mathrm{~N} 7$, which is believed extinct, and $\mathrm{H} 3 \mathrm{~N} 8$, which circulates worldwide. The equine influenza lineages are clearly divergent from avian influenza lineages of the same subtypes. Their genetic evolution and potential for interspecies transmission, as well as clinical features and epidemiology, are discussed. Equine influenza is spread internationally and vaccination is central to control efforts. The current mechanism of international surveillance and virus strain recommendations for vaccines is described.

$\mathrm{T}_{\mathrm{s}}^{\mathrm{h}}$ he story of equine influenza (EI) demonstrates the impact of sociological factors on patterns of infectious diseases. Horses, donkeys, and mules were once common sights on the lanes of cities and towns across the civilized world, working as main vehicles of transport for persons and heavy loads; and it appears that horse $\leftrightarrow$ human interspecies transmission of influenza was a feature of preautomotive society. Morens and Taubenberger (2010b) provide a fascinating review of reports of EI from past centuries back to $1299 \mathrm{AD}$ in the Medieval era and show that an association between EI and human influenza was, for much of that time, believed to exist. Reports of EI epizootics and human epidemics seemed to closely precede or closely follow one another more than half the time. A human influenza-like outbreak in 1872 was popularly called the "epizooty" because of its supposed link with a coincident massive EI outbreak. Possibly in the Medieval/preindustrial era, equids might then have been a mixing vessel for influenza A viral genes much as swine are now. In the twentieth century in first-world countries, automobiles replaced horses and relegated them to a recreational status as a luxury animal, with their population dwindling and almost entirely removed from urban areas; and observations of association between EI and human influenza ceased. Since identification of the known EI viruses (EIVs) more than a halfcentury ago, there is no evidence of genetic reassortment with influenza viruses of any other species. Vaccination is common and $\mathrm{EI}$ is enzootic at usually a low level of severity. In thirdworld countries, equids have in some degree retained their role as primary transportation, and vaccination is rare. The pattern of EI outbreaks in these regions might be presumed to be similar to medieval times, featuring massive high-mortality outbreaks at decadal intervals separated by periods of quiet. Curiously, the

Editors: Gabriele Neumann and Yoshihiro Kawaoka

Additional Perspectives on Influenza: The Cutting Edge available at www.perspectivesinmedicine.org

Copyright (C) 2022 Cold Spring Harbor Laboratory Press; all rights reserved; doi: 10.1101/cshperspect.a038331

Cite this article as Cold Spring Harb Perspect Med 2022;12:a038331 
T.M. Chambers

EIV strains themselves are the same in both parts of the world.

\section{HISTORY}

Influenza-like respiratory disease has been described in horses, as in humans, since Roman times. These were not trivial occurrences: The 1872 epizootic spread throughout much of the United States, facilitated mainly by railroad transport of horses, and also appears to have been associated with an avian influenza outbreak in poultry (Judson 1874; Morens and Taubenberger $2010 \mathrm{a}$ ). In horses it had a mortality rate of $2 \%$, a morbidity rate of nearly $100 \%$, and "literally shut down the United States for several weeks, preventing travel, transportation, mail delivery, and delivery of goods and provisions" (Morens and Taubenberger 2010b). The Great Boston Fire of 1872 was a direct consequence as fire department horses were too sick to pull the fire engines.

The general characteristics of these outbreaks in horses were fever, coughing, and nasal mucous discharge together with rapidly contagious spread. This "influenza syndrome" was probably a common description for respiratory diseases caused by different infectious agents, which were definitively identified in the twentieth century. The major causes of this syndrome are three distinct viruses: EIV, equine herpesvirus (equine rhinopneumonitis), and equine arteritis virus. Of these, EIV is the most common and causes the largest and fastest-spreading outbreaks or epizootics. Bacterial infections such as Streptococcus zooepidemicus are today, and undoubtedly were in ancient times, an important contributing factor to the equine respiratory disease syndrome. Other viruses including adenovirus and rhinovirus are causes of respiratory disease in horses but are not known to cause large-scale disease outbreaks.

The nature of EIV strains circulating prior to the mid-twentieth century is conjectural. The particularly massive EI epizootic in 1872 has been speculated to mark the emergence of the H7N7 subtype of EIV (Worobey et al. 2014). The actual first isolation and biological identification of an EIV was in 1956. This prototype strain is influenza A/equine/Prague/56 virus, which was shown to belong to the subtype H7N7 and termed the A1 or equine-1 subtype (Sovinova et al. 1958). This virus spread to horses in the United States in 1960, although it was not observed to be particularly severe. The genes for the internal proteins of Prague/56 virus have been shown by phylogenetic analysis to be remarkably primitive (Gorman et al. 1990a,b; Ito et al. 1991), forming phylogenetic outgroups to all known avian and mammalian lineages, thus making the Prague/56 virus the most similar to the presumed common ancestor between type $\mathrm{A}$ and B influenza viruses. This lends plausibility to the speculations of an 1872 emergence for this virus. Against this is an analysis of codon usage bias suggesting that H7N7 EIV are less adapted to equine cellular transfer RNA (tRNA) pools than are the more recent H3N8 EIV (Kumar et al. 2016).

In 1963, it was recognized that a new EIV subtype had emerged: Older horses with presumed prior exposure to EI became sick anyway (JT Bryans, pers. comm.). The prototype of this new subtype, termed A2 or equine-2, is the influenza A/equine/Miami/63 strain (Waddell et al. 1963); however, the virus apparently emerged in South America before entering the United States, and the influenza A/equine/Uruguay/63 strain is probably the earliest A2 EIV now known. The A2 EIV are subtype H3N8 and have continuously circulated in horses from 1963 to the present day. Phylogenetic analyses suggest that H3N8 EIV has a complex ancestry. The PA and NP genes apparently diverged from their presumptive avian influenza virus (AIV) ancestral genes prior to 1910 , possibly near the end of the nineteenth century (Okazaki et al. 1989). PB1 may have diverged around the same time or perhaps closer to 1910 (Kawaoka et al. 1989b). However, the PB2, M, and NS genes diverged around the mid-twentith century (Gorman et al. 1990b; Nakajima et al. 1990; Ito et al. 1991). Similarly the hemagglutinin (HA) and neuraminidase (NA) genes are estimated to have originated $1951-1952$ (Bean et al. 1992; Saito et al. 1993). Murcia et al. (2011), rooting their phylogenetic trees through the assumption of a relaxed molecular clock, 
Equine Influenza

calculated that the theoretical most recent common ancestors between the corresponding gene segments of EIV H7N7 and H3N8 most likely dated to 1943-1962 with a mean of 1955 . The route by which this gene constellation came together to become the H3N8 EIV-whether some previously existing EIV was involved or not-is unknown. The pathways of EIV evolution, known and conjectural, are shown in Figure 1.

The A1 (H7N7) and A2 (H3N8) subtypes of EIV cocirculated in horses for some 15 years, and mixed outbreaks of both subtypes have been reported (Tumova 1972). The subtypes reassorted with each other, perhaps more than once (Bean 1984; Ito et al. 1999; Murcia et al 2011). Strains of the A2 subtype were genetically unaffected. However, between 1964 and 1973 the original Prague/56-like A1 strains disap- peared from circulation and were replaced by a variant H7N7 possessing a novel gene constellation consisting of the surface antigens and $M$ gene of the A1/Prague/56 lineage plus the PB1, $\mathrm{PB} 2, \mathrm{PA}, \mathrm{NP}$, and NS genes of the A2/Miami/63 lineage (Ito et al. 1999). This probably prolonged the survival of the A1 lineage in horses for a few years, as the reassortant rapidly replaced the original Prague/56-like strains. The A2 subtype was believed to be the more virulent, but the A1 subtype was the more immunogenic (for which reason it was retained in EI vaccines long after it became irrelevant). This combination of phenotypes, perhaps, is what eventually drove the A1 subtype into extinction in horses. There has not been a confirmed isolate of A1 EIV since 1979 (Webster 1993), and in 2000 the recommendation was made that it be

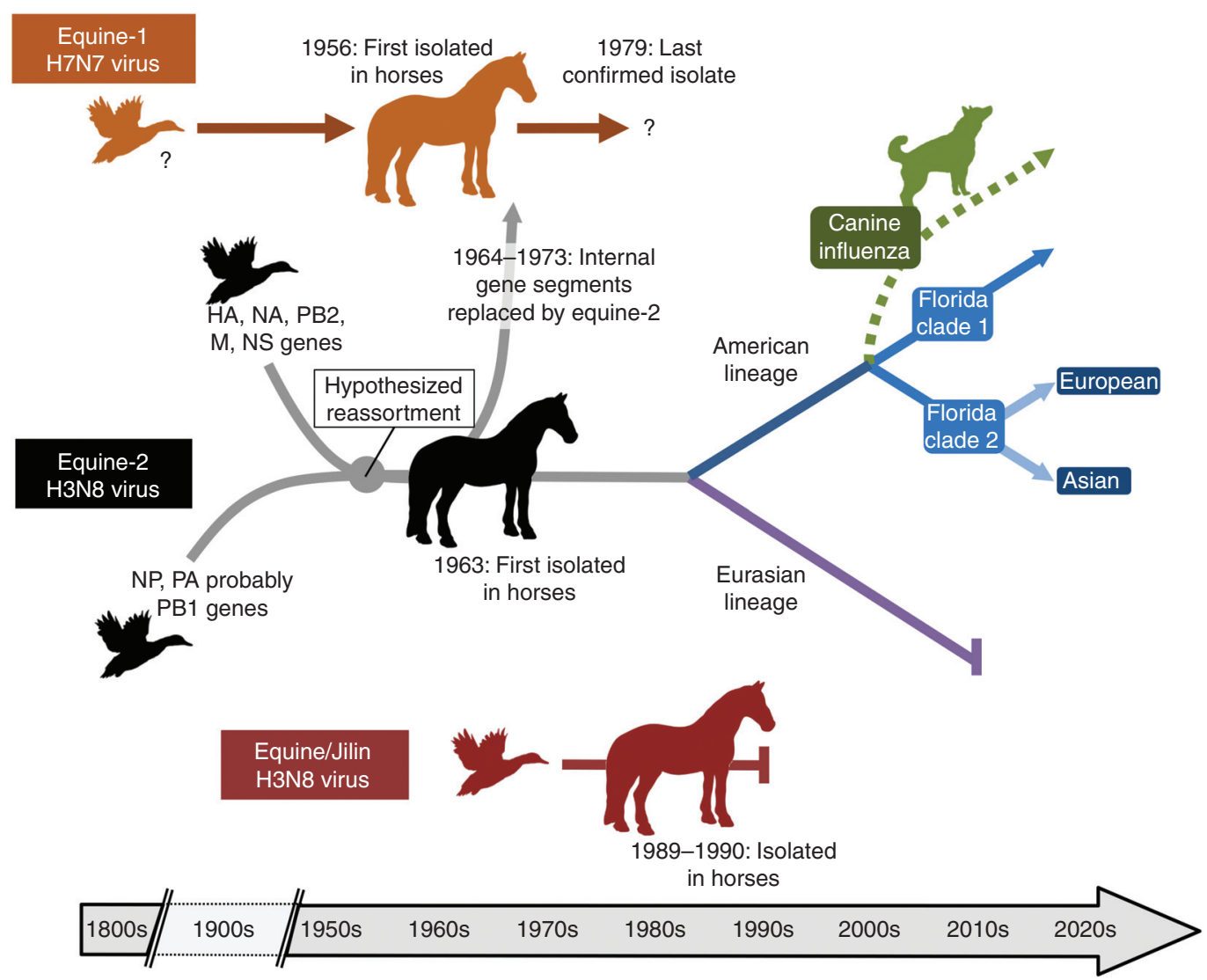

Figure 1. Timeline of evolution of equine influenza viruses (EIVs). Events prior to the first isolations of EIVs in 1956 are conjectural, based on extrapolations of phylogenetic data backward in time. 
T.M. Chambers

dropped from EI vaccines because of its epidemiological irrelevance. However, there have been reports of A1 EI detection in Egypt, India, and Mongolia since 1979 (Ismail et al. 1990; Singh 1994; Yondon et al. 2013)—although without independent confirmation-and the possibility remains that A1 EIV still survive in some hidden reservoir. Reemergence of the H7N7 subtype in horses would necessitate its restoration to vaccines; but until that happens there is no way of knowing whether the reemerged A1 strain would be similar to the A1 strains of the 1960s-1970s, or whether it evolved into a novel variant while it lay hidden.

\section{EVOLUTION AND ANTIGENIC DRIFT}

There has been no known occurrence of true antigenic shift in EIV, although this knowledge only extends back to 1956 . Instead, as discussed above, there was emergence of an entirely new EIV in 1963, the A2 H3N8 subtype, followed eventually by the disappearance of the A1 H7N7 subtype. Within the A2 H3N8 EIV, antigenic drift has been the sole mechanism of their evolution and consequently the major obstacle to their control by vaccination. Evolution of the H3 HA apparently proceeded from 1963 to 1989 in a single main lineage with a side branch that appeared only in 1971-1972 (Kawaoka et al. 1989a), although it must have diverged much earlier. The mutation rate of the main lineage was $1.82 \times 10^{-3}$ nucleotide and 1.41 $\times 10^{-3}$ amino acid substitutions per site per year, only one-third of the rate for human $\mathrm{H} 3 \mathrm{HA}$. A phylogenetic tree of EIV HA1 evolution (kindly provided by Drs. Adam Rash and Debra Elton, Animal Health Trust, United Kingdom) is shown in Figure 2.

In 1989, the main lineage bifurcated into two: the "American" and "Eurasian" lineages
(Daly et al. 1996) based on the locations of isolation of viruses belonging to the different lineages. This split was marked by large severe outbreaks of EI in Europe among vaccinated horses (Livesay et al. 1993). By 1993 the American lineage had also spread to Europe; however, with only one exception the Eurasian lineage never spread to North America. Murcia et al. (2011) have shown that the period of the 1980s was marked by an abrupt drop in EIV genetic diversity, which resumed its former level coinciding with the lineage bifurcation. It has been hypothesized (Koelle et al. 2010; Daly et al. 2013) that the European introduction of quarantine for imported horses in 1986 facilitated the EIV evolution into separate lineages, and later relaxation of quarantine regulations permitted the introduction of the American lineage into Europe. Arguing against this, however, is that the United States had generally weak quarantine restrictions, yet the Eurasian lineage remained excluded.

In 2001 it was shown that the American lineage itself actually consisted of cocirculating Kentucky, Argentina, and Florida sublineages (Lai et al. 2001). These are shown in Figure 2, and taken together they constitute the American lineage described above. The year 2003 was marked by large outbreaks in South Africa and Europe, caused by two different variants of the Florida sublineage. The South Africa outbreak resulted from importation of subclinically infected horses from the United States, and nearly identical virus isolates, including influenza A/equine/South Africa/4/2003, influenza A/equine/Wisconsin/ 2003, and influenza A/equine/Ohio/2003, became the prototypes of the Florida clade 1 sublineage. In Europe the influenza A/equine/ Newmarket/5/2003 strain became the root of the Florida clade 2 sublineage (Bryant et al. 2009). These Florida clades 1 and 2 persist to

Figure 2. (Figure on following page.) Phylogenetic analysis of the hemagglutinin (HA)1 nucleotide sequences encoded by H3N8 equine influenza virus (EIV) through 2015, created using PhyML version 3. Key amino acid substitutions are shown with arrows and those in antigenic sites are underlined. Virus lineages are shown by continuous bars on the right and are labeled appropriately. Current World Organisation for Animal Health (OIE)-recommended vaccine strains are in bold and capitalized. (This tree was generated and kindly provided for use in this review by Drs. Adam Rash and Debra Elton, Animal Health Trust, United Kingdom.) 

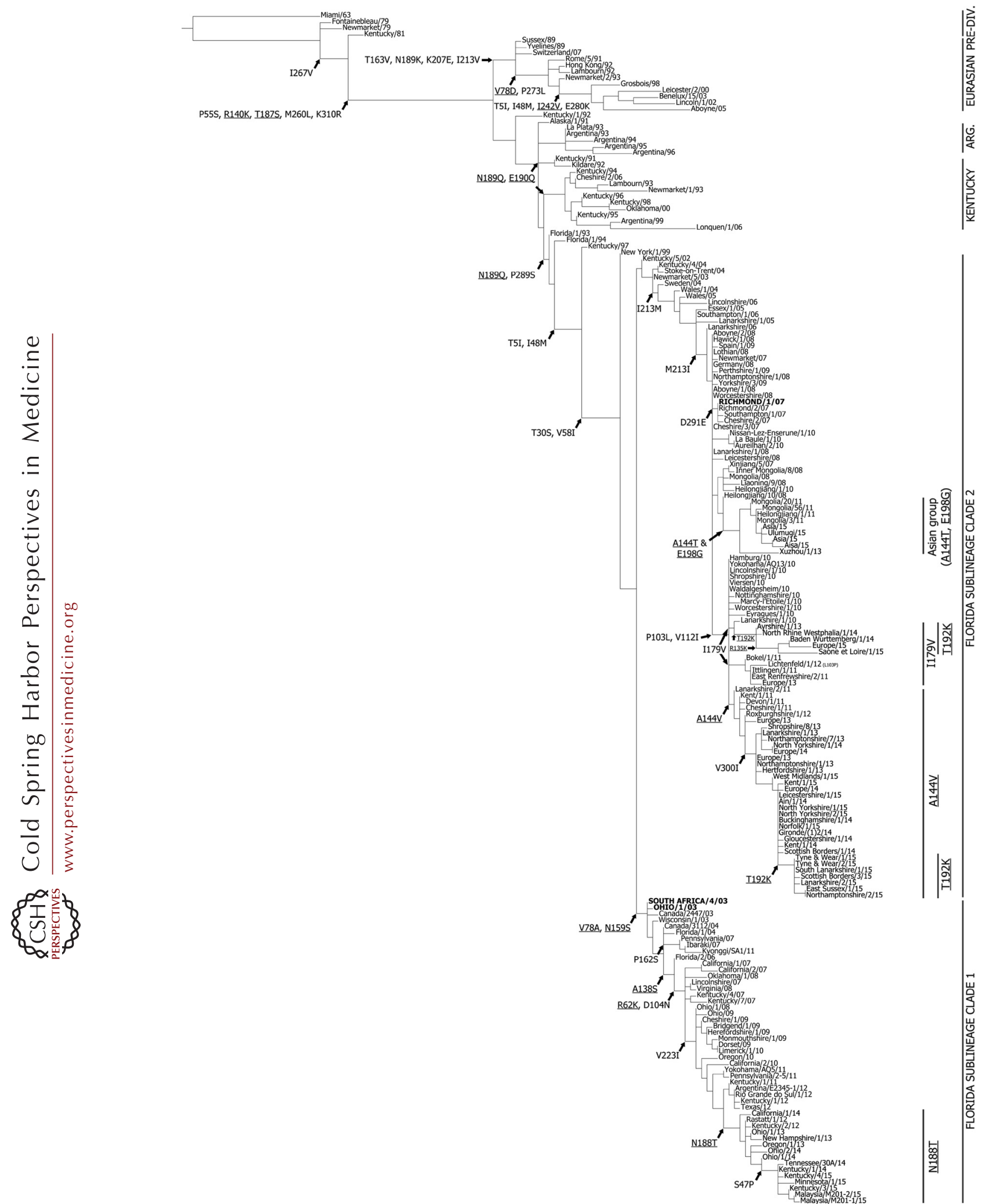

Figure 2. (Legend on previous page.) 
T.M. Chambers

the time of this writing, although for Florida clade 2 the influenza A/equine/Richmond/2007 strain has become the recommended vaccine strain. The Eurasian lineage has not been detected since 2007 and is no longer recommended for inclusion in vaccines. Both Florida clades have circulated around the world but, in a recapitulation of the failure of the Eurasian lineage to establish itself in North America, the Florida clade 2 has been absent from North America save for a few freshly imported horses (Brister et al. 2019). Instead of the misleading geographic identifiers, Murcia et al. (2011) proposed an alternative clade nomenclature and delineated the entire evolution of the equine $\mathrm{H} 3 \mathrm{HA}$ as a succession of 12 distinct clades, including those described above. HA evolution is continuing: A variant Florida clade 2 sublineage has emerged in Asia (Miño et al. 2019). Hughes et al. (2012) showed that within individual horses during an outbreak there are quasispecies mixtures of a dominant virus and multiple minor variants, and frequent transmissions of these mixed variants, demonstrating the mutational substratum that underlies antigenic drift. Transmission bottlenecks are more apparent in vaccinated than naive horses as expected (Murcia et al. 2013).

Murcia et al. (2011) also showed that the other gene segments of H3N8 EIV have evolved into distinguishable clades paralleling those of HA, although the topologies are not precisely the same; indeed, some specific virus strains appear to be intrasubtypic reassortants. As expected, HA (48 amino acid changes along the main trunk branch in 45 years) and NA (50 changes) showed the greatest drift, but PA also showed a high number of changes (45), including some associated with host adaptation. Florida clade 2 strains since Richmond/07 are marked by mutations in all three polymerase genes associated with the emergence of the Asian variant (Bera et al. 2017) and also by a novel 42-amino acid truncation of PA-X (Rash et al. 2014) that possibly affects the virulence of these strains. Evolution of the NS1 gene also has features of interest: Beginning in 1999, EIV with a carboxyterminal truncation of 11 amino acids in NS1 appeared and became dominant (Quinlivan et al. 2005; Bryant et al. 2009). Together with an earlier substitution at E186K, the effect was to alter the mechanism of NS1 anti-interferon (IFN) activity toward interference with the JAK/STAT pathway and so block induction of IFN-stimulated genes (Chauche et al. 2018). EIV virion particles are typically filamentous, although some prototype virus strains including Miami/63 are exceptions (Elton et al. 2013; P Murcia, pers. comm.) This is associated with the M1 protein; however, the precise genetic determinants are different from human and porcine IAV.

In the biological history of EI, two other phenomena are noteworthy. One is "frozen evolution" - that is, detection of H3N8 EIV isolates that are genetically anachronistic, possessing HA sequences of strains that circulated up to 2 decades earlier. This was first described by Endo et al. (1992), who reported HA nucleotide sequences of three EIV strains isolated in 19711988 that had only a small number of nucleotide changes compared to the prototype equine/Miami/63 HA. Similar reports have appeared of strains isolated in 2003-2007 that were similar to the (American lineage) influenza A/equine/ Newmarket/1/93 (Bryant et al. 2009) and (Eurasian lineage) influenza A/equine/Newmarket/ 2/93 strains (Bountouri et al. 2011). In the latter case, the HA was anachronistic but NA was not. Yet another report is of EIV isolated in 2004 that possessed NS genes similar to influenza A/equine/Fontainebleau/79 (Boukharta et al. 2015). Other reports show similar examples (Manuguerra et al. 2000; Borchers et al. 2005). Because Miami/63 and both Newmarket/93 strains were used in vaccines, this raises the possibility of laboratory escape; however, that is difficult to prove. Finally, in one of the few examples of EIV interspecies transmission, $\mathrm{Tu}$ et al. (2009) reported that during swine surveillance in 2005 and 2006, they had from pigs isolated viruses whose nearest neighbors in all eight gene segments were EIV from Europe 19911993. The frozen evolution phenomenon is worrisome for vaccination efforts as it raises the possibility of hidden reservoirs in which EIV can be maintained for decades with little change and then reemerge into horses after their correlated vaccine strains have been abandoned as 
outdated. So far, however, these reemergences have not triggered outbreaks, and vaccines using current strains might still confer sufficient immunity to limit infections with old strains.

The second unusual phenomenon was a massive outbreak of H3N8 influenza in horses and donkeys in Jilin and Heilonjiang provinces of China in 1989. The causative virus, influenza A/equine/Jilin/89, was shown to be of avian origin in all eight gene segments and not a typical A2 EIV at all (Webster and Guo 1991). This outbreak infected 20,000 horses with some 400 deaths. The avian-like Jilin/89 strain has not been detected since 1990. Serology studies in 1993-1994 raised the possibility that it might still be circulating at that time (Guo et al. 1995), but probably it was extinguished either by exhausting available hosts or by competition with authentic EIV circulating in the region. Contemporary EIV vaccines showed cross protection against the Jilin/89 strain in a mouse model, and a low level of cross-reactivity by postvaccination equine sera (Chambers 1992; Webster and Thomas 1993). This avian-toequine interspecies transmission event has not been observed to reoccur since the Jilin outbreak, although genetically related viruses continue to be maintained in avian reservoirs in northern China (Pu et al. 2009), and AIV with individual EIV-like gene segments (e.g., NS [Spackman et al. 2006], PB1, and PA [Hurt et al. 2014]) have been detected. It is interesting that this avian $\mathrm{H} 3 \mathrm{~N} 8$ virus adapted-once-to horses so easily as to spread rapidly to 20,000 horses, whereas the observable trend of other AIV in, for example, humans has been that initial infections have occurred many times but human-to-human spread has been practically nil.

\section{INTERSPECIES TRANSMISSION}

The Jilin event shows that such interspecies transmission into horses can occur and supports the phylogenetic conclusion that the $\mathrm{A} 2 \mathrm{H} 3 \mathrm{~N} 8$ subtype of EIV likely originated from avian influenza virus ancestors. Zhu et al. (2019), in a serological study in Mongolia, identified 97 horses of 585 tested that were seropositive for avian $\mathrm{H} 3 \mathrm{~N} 8$ influenza viruses, including 18 that were also seronegative for equine $\mathrm{H} 3 \mathrm{~N} 8$ strains. They also showed that avian H3N8 viruses did replicate in explanted equine trachea but without cytopathic effect. These authors suggest that AIV $\rightarrow$ horse transmission may be more common than supposed but without clinical signs and thus goes undetected with limited or no spread to other horses. Based on sequence comparisons of H3N8 AIV isolates with the equine/ Jilin/89 virus, they also suggest that in five of the eight viral RNA segments the mutational hurdle for AIV $\rightarrow$ horse adaptation may be small. If so, because H3N8 EIV are enzootic in Mongolia, reassortment between AIV and EIV in horses to yield a new highly transmittable emerging EIV is a clear possibility.

Other subtypes of low-pathogenicity AIV can replicate in explanted equine trachea but were similarly undetectable when experimentally administered into horses (Chambers et al. 2013). However, highly pathogenic H5N1 AIV was isolated from moderately diseased donkeys in Egypt (Abdel-Moneim et al. 2010), and a similar unconfirmed report came from Pakistan (A Khan, King Edward Medical University, Lahore, pers. comm.). Antibodies to influenza D virus have also been detected in horses (Nedland et al. 2018), although as yet no virus isolate from horses has been obtained.

EIV itself can spread from horses into other mammals. Its spread into canines is discussed extensively in Wasik et al. (2020). The report of anachronistic EIV isolated from pigs (Tu et al. 2009) is mentioned above. Against this, Patrono et al. (2015) and Solórzano et al. (2015) experimentally found that, with the exception of the very early Uruguay/1963, most H3N8 EIV strains (and canine influenza virus [CIV]) had little or no capability to replicate in pig tracheal explants or to infect pigs. H3N8 EIV was also isolated from a Bactrian camel (Yondon et al. 2014). Experimentally, cats are also susceptible to H3N8 EIV infection (Su et al. 2014).

Debate over the capacity of EIV for interspecies transmission into humans arises in part from the ancient history of the disease discussed above, but more importantly from serological evidence and from experimental infections of 
T.M. Chambers

human volunteers (for review, see Xie et al. 2016). Seroarchaelogy studies from 1965 detected antibodies reactive with $\mathrm{H} 3 \mathrm{~N} 8 \mathrm{EIV}$ in elderly humans whose exposure must have occurred in 1890 (Minuse et al. 1965; Schild and StuartHarris 1965; Masurel and Mulder 1966). These results are sometimes interpreted to indicate that an H3 EIV entered humans from horses to cause the 1889 (or alternatively 1896) human influenza pandemic. That is certainly a possibility; but context is needed. For the 1965-1966 seroarchaeology studies, the H3N8 EIV, newly discovered in 1963, was the only $\mathrm{H} 3$ viral antigen tested; human and swine $\mathrm{H} 3$ viruses were not yet known. Those studies indicate that a subtype H3 virus circulated in humans in the late nineteenth century, but the 1963 EIV is most likely not a relic or descendent of that virus: as discussed above, phylogenetically the HA of H3N8 EIV seems to have emerged in $\sim 1950$. The antigenic relationship shown by seroarchaeology could be coincidental rather than causative.

The experimental human studies, also from 1965-1966, showed a usually low or subclinical level of infection occurred in approximately two-thirds of volunteers inoculated (Alford et al. 1967; Couch et al. 1969; Kasel and Couch 1969). Thus, the possibility of human infection with H3N8 EIV cannot be discounted. Recent serological studies in Australia, Mongolia, and the United States indicate that antibodies to H3N8 EIV may be detected in $~ 3 \%-10 \%$ of study participants, principally those with occupational horse exposure (Burnell et al. 2014; Khurelbaatar et al. 2014; Larson et al. 2015). Mainly the measured antibody titers were below a level indicative of acute infection and might have been associated with the cross-reacting antibody to human $\mathrm{H} 3$ influenza. To date there has never been any confirmed report, with virus isolate, of any clinical case of EI in humans. This still leaves open the future possibility of subclinical EIV infection leading to reassortment with human influenza to produce a genetically novel, possibly virulent virus strain.

Restricted EIV transmission into humans, typically yielding subclinical infections, appears to be strongly correlated with EIV receptor binding specificity (for review, see Suzuki
2005). Like AIV, and unlike human influenza, EIV HA shows strongly preferential binding to terminal sialic acid $\alpha 2,3 \mathrm{Gal}$ (Suzuki et al. 2000). However, the predominant terminal sialyloligosaccharide in the respiratory tract of horses, constituting $>90 \%$ of the total sialic acids in horse tracheal epithelium, is $\mathrm{N}$-glycolylneuraminic acid (NeuGc), rather than $N$-acetylneuraminic acid (NeuAc) that predominates in most birds (Suzuki et al. 2000; Broszeit et al. 2019). NeuGC is also present in pigs but is largely absent from humans except when obtained from food (Takahashi et al. 2014). EIV of both H7 and H3 subtypes bind both NeuGC- and NeuAc- $\alpha 2,3 \mathrm{Gal}$, and EIV of the H7 subtype in particular show higher avidity for NeuGC than NeuAc (Gambaryan et al. 2012). Mutant EIV with human-like HA, and strong $\alpha 2,6 \mathrm{Gal}$-binding preference, failed to detectably replicate in experimentally infected ponies (Suzuki et al. 2000). It has been suggested that in humans, NeuGc works as a "decoy receptor" rather than a functional receptor for NeuGc-binding influenza viruses (Takahashi et al. 2014), and EIV entering humans would be particularly susceptible to such decoy activity. It is also possible that in horses, the greater avidity of H7 EIV for the NeuGc receptor was somehow a selective disadvantage that contributed to their being outcompeted by H3 EIV (Broszeit et al. 2019).

\section{CLINICAL FEATURES}

The clinical presentation of EI has been reviewed (Gerber 1970; Wilson 1993; Cullinane 1997; Landolt et al. 2014). Briefly, in susceptible horses EI is characterized by pyrexia, a dry hacking cough and nasal discharge. Submandibular and retropharyngeal lymphadenopathy are sometimes but not always present and may be associated with an active immune response. Other signs can include anorexia and lethargy. Exercise stress increases a horse's susceptibility to EI (Gross et al. 1998; Folsom et al. 2001; Newton and Mumford 2005). Severe infections often feature tachypnea and inspiratory/expiratory wheeze (Beech 1991). Histologic findings include rhinitis or tracheitis at the time of the initial febrile response together with epithelial 
Equine Influenza

degeneration/necrosis and increasing lymphocytic infiltration of the lamina propria; following the acute stage of infection there is epithelial hyperplasia or squamous metaplasia (Begg et al. 2011; Muranaka et al. 2012). Hemocytologic findings may feature normocytic, normochromic anemia, neutropenia, lymphopenia, and sometimes monocytosis during early convalescence (Gerber 1970).

A prolonged or recurring spike of fever generally indicates secondary bacterial infection in the airways. These are usually opportunistic infections caused by $\beta$-hemolytic streptococci (Sarasola et al. 1992; Liu 1993; Kästner et al. 1999; Newton et al. 1999; Morley 2004), particularly S. zooepidemicus (Anzai et al. 2000; Muranaka et al. 2012) already resident in the nasal passages. Other causative organisms include Gram-negative bacteria such as Actinobacillus spp. (Wilson 1993). These can potentially trigger a life-threatening bacterial pleuropneumonia (Mumford et al. 1990; Austin et al. 1995; Gross et al. 1998; Anzai et al. 2000; Barr 2003). EI infection promotes these bacterial pneumonias because virus replication leads to apoptotic death of the ciliated epithelial cells lining the trachea and bronchial tree (O'Niell et al. 1984; Lin et al. 2001). The trachea may be denuded of ciliated epithelial cells, which disrupts the mucociliary escalator, an important defense mechanism against these opportunistic bacteria (Willoughby et al. 1992). Deeper in the respiratory tract (bronchioles), total cell death in experimentally infected ponies was estimated at $\sim 27 \%$ (Saenz et al. 2010). Other disease signs may include myositis, myocarditis, and limb edema (Gerber 1970). There is a possible association with development of chronic inflammatory airway disease, recurrent airway obstruction, or exercise-induced pulmonary hemorrhage. Lastly, neurological disease in the form of a nonsuppurative encephalitis has been observed, although rarely (Daly et al. 2006). EIV has not been detected in the central nervous system.

In susceptible horses, the morbidity rate is $60 \%-90 \%$. In large groups of horses that have varying degrees of previous exposure to EI or EI vaccines, the morbidity rate may range from
$20 \%$ to $37 \%$ (Powell et al. 1995; Morley et al 2000 ). The mortality rate is usually $<1 \%$ (Guo et al. 1994), but higher death rates have been reported during some epizootics (Yondon et al. 2013), particularly in donkeys and sometimes in neonatal foals (Alexander and Brown 2000; Peek et al. 2004; Gilkerson 2011). Outbreaks caused by a novel strain of EI may be exceptions. One such exception was the 1989 influenza outbreak in the People's Republic of China caused by an avian-lineage $\mathrm{H} 3 \mathrm{~N} 8$ virus; this produced a mortality rate of $20 \%$ in some herds (Guo et al. 1992), although much less overall. As secondary bacterial pneumonias are a common feature of EI, probably the mortality rate is strongly influenced by prompt access to veterinary care including antibiotic treatment and $1-3$ wk of rest, which may be unavailable to working equids in third-world countries.

Experimentally, in naive animals the typical EI disease course is that following exposure there is a latent period of $1-2 \mathrm{~d}$, followed by an infectious period of $\sim 5 \mathrm{~d}$ (Park et al. 2003). Vaccination status alters these values depending on the similarity of vaccine strain to challenge virus. The actual febrile period starts at $2 \mathrm{~d}$ and, in uncomplicated infections, may only last $1-2 \mathrm{~d}$ even though there is still active virus replication. Viral RNA can be detected by reverse transcription polymerase chain reaction (RT-PCR) for an additional week or sometimes longer beyond the end of detectable live virus shedding (Read et al. 2011). In field outbreaks involving vaccinated populations, the apparent latent period, based on retrospective analysis, can sometimes be surprisingly long, from 1 to $4 \mathrm{wk}$ before clinical signs are noticed (Powell et al. 1995). The reproduction number, $R_{0}$, has been variously estimated between 2 and 10 , but a recent estimate is that it decreases from 3.9 to 1.5 during the course of an outbreak (Hughes et al. 2012).

The severity of EI disease varies from horse to horse, mainly but not entirely determined by the level of immunity of the horse. If a horse has some level of immunity to EIV, through either vaccination or previous infection, that immunity should reduce the severity of disease or result in the horse having no clinical signs but still shedding virus (subclinical infection). A horse 
T.M. Chambers

with robust immunity, following recent vaccination (between 2 and 6 wk following completion of the primary course) or recent infection (within the previous 8 mo [see Hannant et al. 1988]), may resist infection completely (sterile immunity, no virus shedding). In vaccinated horses the extent of antigenic similarity between the vaccine virus strains and the infecting virus strain also affects the outcome. Mathematical modeling suggests that vaccination with mismatched virus strains is probably of limited consequence for an individual animal as some cross-reaction is likely; but at the population level a mismatched vaccine increases the possibility of a larger outbreak occurring (Park et al. 2003, 2009; Daly et al. 2013). The age and sex of the horse also play roles in its resistance to EI (e.g., Newton et al. 2006). In younger horses there is an "immunity gap" resulting from rapid declines in serum antibody titers before their next scheduled vaccination (Cullinane et al. 2001); whereas antibody titers in older horses are more stable. Newton et al. (2006) reported, however, that older horses are at greater risk despite antibody titers similar to younger horses, perhaps as a consequence of original antigenic sin. The perceived lower incidence of EI in older horses may be due instead to lower rates of exposure. Males are generally more susceptible and also respond to vaccination with lower titers than females (Ryan et al. 2015). Exercise stress or transport stress can also increase susceptibility to EI (Folsom et al. 2001).

\section{EPIDEMIOLOGY AND IMPACT}

EI is an international disease. Horses travel internationally for breeding and performance purposes and in larger numbers than any other domestic mammal. Modern air transport enables the spread of infectious respiratory diseases, much more so than did transoceanic shipping of the nineteenth and earlier centuries in which the long duration of the ocean voyage served as a quarantine period allowing highly contagious diseases to burn themselves out: Probably for that reason the 1872 EI epizootic in the United States did not spread to Europe. Among countries with significant horse indus- tries, only New Zealand and Iceland have succeeded in staying continuously free of EI. Other countries including mainly Australia, Japan, and South Africa have experienced EI epizootics but were able to contain and eliminate them from their domestic horse populations. In most of the world including North and South America, Europe, and Asia, EI is either enzootic at some low level or else there is a history of repeated epizootics for which the route of virus introduction is usually unknown. EI is not considered a seasonal disease, but in Europe and the United States, EI may be more prevalent in the springtime (Morley et al. 2000; Newton et al 2000 ), which is probably an effect of management schedules. Epizootics can occur whenever the virus is introduced into a susceptible population (Morley 2004).

All equid species including horses, ponies, donkeys, and zebras are susceptible to EI infection (Nyaga et al. 1980; Virmani et al. 2010; Happold and Rubira 2011). Abattoirs may be virus reservoirs (A Cullinane, pers. comm.). In foals, EI can be life-threatening (Peek et al. 2004) but occurs rarely except in the circumstance of failure of passive transfer of maternal antibodies from an EI-immune dam (Smith 1979).

Transmission of EIV from an infected horse to a susceptible horse can occur by direct horseto-horse contact, by inhalation of aerosolized droplets coughed out by the infected animal, or by fomite transmission. The distance over which aerosolized droplets can effectively transmit influenza is a subject of conjecture. Horses cough more forcefully than humans, swine, or ferrets. The historical EIV literature lists 35 yards (Miller 1966; Gerber 1970) as the expected distance that aerosols could transmit to another horse. There is no clear evidence of open-air transmission of EIV at levels high enough to cause infections in horses over many hundreds of meters. However, there are statistical associations of prevailing wind direction with farm-tofarm spread of EI infection during the epizootic in Australia in 2007 (Davis et al. 2009; Firestone et al. 2012). When using PCR for detection, airborne influenza viruses have been detected in wind-driven plumes at $>1 \mathrm{~km}$ downwind from swine barns housing large numbers of influenza- 
infected swine (Corzo et al. 2013). Possibly there may exist a set of environmental conditions (temperature, humidity, wind speed, and direction) and epidemiological conditions (source of many coughing horses, a susceptible target population) that could support longer-range transmission of infectious-dose levels of EIV, but the risk is unknown.

There are no reports of EIV in semen or blood of infected horses nor is it sexually transmissible in the horse (Samper and Tibary 2006). Similarly, there are no reports of EIV transmission by blood-feeding insects. It could be argued in principle that birds could carry EIV and spread it through their droppings; but this has never been demonstrated in the field. Horse $\rightarrow$ dog transmission has occurred (see Wasik et al. 2020), but the reverse ( $\operatorname{dog} \rightarrow$ horse) seems experimentally to be very inefficient (Yamanaka et al. 2010; Quintana et al. 2011).

Mathematical modeling suggests that in vaccinated horse populations, as is common in first-world countries with dedicated horse industries, the majority of EI outbreaks tend to be limited in size. This is confirmed by observation in the United States, the United Kingdom, and the rest of Europe: EIV is enzootic but small numbers of animals (typically fewer than 100 annually in each) are reported as affected. This understates the true virus circulation (probably by at least one order of magnitude) as subclinical cases are likely to go unreported and surveillance is leaky. Particularly in the United States, where EI is not a reportable disease, even clinical case samples may not be submitted for laboratory confirmation. In Europe and the United Kingdom, especially severe outbreaks of EI occurred in 1989, 2003, and 2018-2019. Each affected approximately 5000 to 10,000 horses and was associated with a new branch (or in 2018, a long-absent branch) of EIV evolution (e.g., Newton et al. 2006). However, mortality remained low. EIV was still detected at its usual level in between these epizootics.

In third-world countries, equids are heavily worked and seldom vaccinated. EI may appear to be entirely absent for decade-long intervals and then erupt in huge epizootics with high mortality. In Mongolia, Yondon et al. (2013) reported a succession of EI outbreaks in different decades, each affecting some half-million horses with mortality rates of $\sim 20 \%$ until vaccination became common. An active surveillance program instituted in 2016 showed a low level of sporadic EI in Mongolia since the most recent epizootic (Sack et al. 2017). A possible explanation for this pattern is that the explosive epizootics create a prevailing high level of herd immunity that suppresses EIV circulation (below the threshold of surveillance) more effectively than vaccination alone, but weakens over time without restimulation.

The 2007 EI epizootic in Australia was a novel and instructive situation in which the resident horse population was both well-managed and completely naive to EI. Australia had historically been free from the disease and, to remain so, operated a quarantine system for imported horses. This epizootic began when EIV from a newly imported horse escaped the quarantine facility, possibly carried by fomites. To contain the outbreak, Australian authorities instituted strict horse movement restrictions within the affected area, together with a program of ring vaccination using a vaccine allowing the serological differentiation of infected from vaccinated animals (DIVA [differentiating infected from vaccinated]-capable vaccine, in this case inducing antibodies to HA but not to NA) to limit the enlargement of that area. Eventually the outbreak was successfully contained after some 70,000 horses had been affected. Mortality was very low because of the close monitoring and veterinary care. Australia was again certified as EI-free in 2008 (Callinan 2008).

\section{VACCINES}

Influenza vaccines have been available since the mid-1960s. The majority are inactivated whole virus formulated with adjuvants, but today there are also products using immune-stimulating complexes (ISCOMs), live recombinant canarypox, and cold-adapted EIV (for review, see Paillot 2014). Reverse genetics-based approaches and DNA vaccination have been tested with success (Chambers et al. 2009; Ault et al. 2012; Rodriguez et al. 2018). To be effective, influenza 
T.M. Chambers

vaccines need to be periodically updated to keep up with the emergence of novel antigenic variants. As discussed above, the rate of change in the HA/NA from antigenic drift is slower in equine influenza viruses than in human influenza viruses (Bean et al. 1992; Endo et al. 1992; Daly et al. 1996; Murcia et al. 2011). The slower rate of evolution is reflected in the continued use of "old" virus strains (e.g., Ohio/2003) as vaccine strains more than 15 years after their isolation. At some point, however, these will be antigenically no longer representative of EIV strains in active circulation and become obsolete as vaccine strains. Previous vaccine strains (e.g., Miami/63, Fontainebleau/79, and influenza $\mathrm{A} /$ equine/Kentucky/81) were all thus rendered obsolete, as was evidenced by outbreaks in vaccinated herds (Mumford 1990; Powell et al. 1995). Through the mid-1990s, antigenic drift was generally assessed only in retrospect of vaccine failures in the field. This was not satisfactory. Dedicated surveillance systems for EIV outbreaks have been established in some countries (e.g., Legrand et al. 2013; Woodward et al. 2014). To track ongoing antigenic drift in EIV worldwide and make vaccine strain recommendations to manufacturers and regulatory agencies, the EIV research community in 1995 set up a permanent task force, the Expert Surveillance Panel (Cullinane et al. 2010). This panel collects epidemiological information on new EIV outbreaks, performs genetic and antigenic analyses of new EIV isolates, and reports its findings to the Office International des Epizooties, which publishes the conclusions and recommendations annually in its Bulletin. Regulatory agencies such as the European Medicines Agency (EMA) and U.S. Department of Agriculture (USDA) consider these recommendations when new vaccine products are submitted for licensure. HA sequencing and hemagglutinin inhibition (HI)based antigenic cartography (Lewis et al. 2011) are the virological factors carrying the greatest weight. Other viral gene segments, particularly $\mathrm{NA}$, are also now routinely sequenced, and it is likely that changes in these will assume greater weight as their effects become better understood. There are small-animal (mouse, hamster) models of EIV infection (Daly et al. 2003; Pavulraj et al.
2015), but there is also a well-established experimental challenge model for EIV in horses that is used to test vaccine efficacies or other virus-host interactions in the natural host (Mumford et al. 1990; Garrett et al. 2017).

\section{ACKNOWLEDGMENTS}

We thank Ms. Diane Furry (University of Kentucky) for creation of Figure 1 and Drs. Adam Rash and Debra Elton, Animal Health Trust, United Kingdom, for the generation of the phylogenetic tree presented as Figure 2. T.M.C. is supported by a project of the Kentucky Agricultural Experiment Station (KY014053).

This article has been made freely available online courtesy of TAUNS Laboratories.

\section{REFERENCES}

* Reference is also in this collection.

Abdel-Moneim AS, Abdel-Ghany AE, Shany SA. 2010. Isolation and characterization of highly pathogenic avian influenza virus subtype H5N1 from donkeys. J Biomed Sci 17: 25. doi:10.1186/1423-0127-17-25

Alexander DJ, Brown IH. 2000. Recent zoonoses caused by influenza A viruses. Rev Sci Tech 19: 197-225. doi:10 $.20506 /$ rst.19.1.1220

Alford RH, Kasel JA, Lehrich JR, Knight V. 1967. Human responses to experimental infection with influenza A/Equi 2 virus. Am J Epidemiol 86: 185-192. doi:10 .1093/oxfordjournals.aje.a120723

Anzai T, Walker JA, Blair MB, Chambers TM, Timoney JF. 2000. Comparison of the phenotypes of Streptococcus zooepidemicus isolated from tonsils of healthy horses and specimens obtained from foals and donkeys with pneumonia. Am J Vet Res 61: 162-166. doi:10.2460/ajvr .2000 .61 .162

Ault A, Zajac AM, Kong WP, Gorres JP, Royals M, Wei CJ, Bao S, Yang ZY, Reedy SE, Sturgill TL, et al. 2012. Immunogenicity and clinical protection against equine influenza by DNA vaccination of ponies. Vaccine 30: 3965-3974. doi:10.1016/j.vaccine.2012.03.026

Austin SM, Foreman JH, Hungerford LL. 1995. Case-control study of risk factors for development of pleuropneumonia in horses. J Am Vet Med Assoc 207: 325-328.

Barr BS. 2003. Pneumonia in weanlings. Vet Clin North Am Equine Pract 19: 35-49. doi:10.1016/S0749-0739 (02)00065-2

Bean WJ. 1984. Correlation of influenza A virus nucleoprotein genes with host species. Virology 133: 438-442. doi:10.1016/0042-6822(84)90410-0

Bean WJ, Schell M, Katz J, Kawaoka Y, Naeve C, Gorman O, Webster RG. 1992. Evolution of the H3 influenza virus 
hemagglutinin from human and nonhuman hosts. J Virol 66: 1129-1138. doi:10.1128/JVI.66.2.1129-1138.1992

Beech J. 1991. Infections caused by viruses. In Equine respiratory disorders (ed. Beech J), pp. 153-180. Lea \& Febiger, Philadelphia.

Begg AP, Reece RL, Hum S, Townsend W, Gordon A, Carrick J. 2011. Pathological changes in horses dying with equine influenza in Australia, 2007. Aust Vet J 89: 19-22. doi:10.1111/j.1751-0813.2011.00731.x

Bera BC, Virmani N, Kumar N, Anand T, Pavulraj S, Rash A, Elton D, Rash N, Bhatia S, Sood R, et al. 2017. Genetic and codon usage bias analyses of polymerase genes of equine influenza virus and its relation to evolution. BMC Genomics 18: 652. doi: 10.1186/s12864-017-4063-1

Borchers K, Daly J, Stiens G, Kreling K, Kreling I, Ludwig H. 2005. Characterisation of three equine influenza A H3N8 viruses from Germany (2000 and 2002): evidence for frozen evolution. Vet Microbiol 107: 13-21. doi:10.1016/j .vetmic.2005.01.010

Boukharta M, Azlmat S, Elharrak M, Ennaji MM. 2015 Multiple alignment comparison of the nonstructural genes of three strains of equine influenza viruses (H3N8) isolated in Morocco. BMC Res Notes 8: 471. doi:10.1186/s13104-015-1441-0

Bountouri M, Fragkiadaki E, Ntafis V, Kanellos T, Xylouri E. 2011. Phylogenetic and molecular characterization of equine H3N8 influenza viruses from Greece (2003 and 2007): evidence for reassortment between evolutionary lineages. Virol J 8: 350. doi:10.1186/1743-422X-8-350

Brister H, Barnum SM, Reedy S, Chambers TM, Pusterla N. 2019. Validation of two multiplex real-time PCR assays based on single nucleotide polymorphisms of the HA1 gene of equine influenza $\mathrm{A}$ virus in order to differentiate between clade 1 and clade 2 Florida sublineage isolates. J Vet Diagn Invest 31: 137-141. doi:10.1177/ 1040638718822693

Broszeit F, Tzarum N, Zhu X, Nemanichvili N, Eggink D, Leenders T, Li Z, Liu L, Wolfert MA, Papanikolaou A, et al. 2019. N-glycolylneuraminic acid as a receptor for influenza A viruses. Cell Rep 27: 3284-3294.e6. doi:10.1016/ j.celrep.2019.05.048

Bryant NA, Rash AS, Russell CA, Ross J, Cooke A, Bowman S, MacRae S, Lewis NS, Paillot R, Zanoni R, et al. 2009. Antigenic and genetic variations in European and North American equine influenza virus strains (H3N8) isolated from 2006 to 2007. Vet Microbiol 138: 41-52. doi:10 .1016/j.vetmic.2009.03.004

Burnell FJ, Holmes MA, Roiko AH, Lowe JB, Heil GL, White SK, Gray GC. 2014. Little evidence of human infection with equine influenza during the 2007 epizootic, Queensland, Australia. J Clin Virol 59: 100-103. doi:10.1016/j.jcv .2013.11.011

Callinan I. 2008. Equine influenza: the August 2007 outbreak in Australia. Report of the Equine Influenza Inquiry. https ://trove.nla.gov.au/version/30659476

Chambers TM. 1992. Cross-reactivity of existing equine influenza vaccines with a new strain of equine influenza virus from China. Vet Rec 131: 388-391. doi:10.1136/vr .131 .17 .388

Chambers TM, Quinlivan M, Sturgill T, Cullinane A, Horohov DW, Zamarin D, Arkins S, García-Sastre A, Palese P. 2009. Influenza A viruses with truncated NS1 as mod- ified live virus vaccines: pilot studies of safety and efficacy in horses. Equine Vet J 41: 87-92. doi:10.2746/ 042516408X371937

Chambers TM, Balasuriya UB, Reedy SE, Tiwari A. 2013. Replication of avian influenza viruses in equine tracheal epithelium but not in horses. Influenza Other Respir Viruses 7: 90-93. doi:10.1111/irv.12188

Chauche C, Nogales A, Zhu H, Goldfarb D, Ahmad Shanizza AI, Gu Q, Parrish CR, Martínez-Sobrido L, Marshall JF, Murcia PR. 2018. Mammalian adaptation of an avian influenza A virus involves stepwise changes in NS1. J Virol 92: e01875-17.

Corzo CA, Culhane M, Dee S, Morrison RB, Torremorell M. 2013. Airborne detection and quantification of swine influenza A virus in air samples collected inside, outside and downwind from swine barns. PLoS ONE 8: e71444. doi:10 .1371/journal.pone.0071444

Couch RB, Douglas RG, Kasel JA, Riggs S, Knight V. 1969. Production of the influenza syndrome in man with equine influenza virus. Nature 224: 512-514. doi:10.1038/ $224512 \mathrm{a} 0$

Cullinane A. 1997. Viral respiratory disease. In Current therapy in equine medicine (ed. Robinson NE), Vol. 4, pp. 443-448. W.B. Saunders, Philadelphia.

Cullinane A, Weld J, Osborne M, Nelly M, McBride C, Walsh C. 2001. Field studies on equine influenza vaccination regimes in thoroughbred foals and yearlings. Vet J 161: 174-185. doi:10.1053/tvjl.2000.0546

Cullinane A, Elton D, Mumford J. 2010. Equine influenzasurveillance and control. Influenza Other Respir Viruses 4: 339-344. doi:10.1111/j.1750-2659.2010.00176.x

Daly JM, Lai AC, Binns MM, Chambers TM, Barrandeguy M, Mumford JA. 1996. Antigenic and genetic evolution of equine H3N8 influenza A viruses. J Gen Virol 77: 661671. doi:10.1099/0022-1317-77-4-661

Daly JM, Yates RJ, Browse G, Swann Z, Newton JR, Jessett D, Davis-Poynter N, Mumford JA. 2003. Comparison of hamster and pony challenge models for evaluation of effect of antigenic drift on cross protection afforded by equine influenza vaccines. Equine Vet $J$ 35: 458-462. doi:10.2746/042516403775600433

Daly JM, Whitwell KE, Miller J, Dowd G, Cardwell JM, Smith KC. 2006. Investigation of equine influenza cases exhibiting neurological disease: coincidence or association? J Comp Pathol 134: 231-235. doi:10.1016/j.jcpa .2005 .09 .001

Daly JM, Newton JR, Wood JL, Park AW. 2013. What can mathematical models bring to the control of equine influenza? Equine Vet J 45: 784-788. doi:10.1111/evj.12104

Davis J, Garner MG, East IJ. 2009. Analysis of local spread of equine influenza in the Park Ridge region of Queensland. Transbound Emerg Dis 56: 31-38. doi:10.1111/j.18651682.2008.01060.x

Elton D, Bruce EA, Bryant N, Wise HM, MacRae S, Rash A, Smith N, Turnbull ML, Medcalf L, Daly JM, et al. 2013 The genetics of virus particle shape in equine influenza $\mathrm{A}$ virus. Influenza Other Respir Viruses 7: 81-89. doi:10 $.1111 /$ irv.12197

Endo A, Pecoraro R, Sugita S, Nerome K. 1992. Evolutionary pattern of the $\mathrm{H} 3$ haemagglutinin of equine influenza viruses: multiple evolutionary lineages and frozen replication. Arch Virol 123: 73-87. doi:10.1007/BF01317139 
T.M. Chambers

Firestone SM, Cogger N, Ward MP, Toribio J-ALML, Moloney BJ, Dhand NK. 2012. The influence of meteorology on the spread of influenza: survival analysis of an equine influenza (A/H3N8) outbreak. PLoS One 7: e35284. doi:10.1371/journal.pone.0035284

Folsom RW, Littlefield-Chabaud MA, French DD, Pourciau SS, Mistric L, Horohov DW. 2001. Exercise alters the immune response to equine influenza virus and increases susceptibility to infection. Equine Vet J 33: 664-669. doi:10.2746/042516401776249417

Gambaryan AS, Matrosovich TY, Philipp J, Munster VJ, Fouchier RA, Cattoli G, Capua I, Krauss SL, Webster RG, Banks J, et al. 2012. Receptor-binding profiles of H7 subtype influenza viruses in different host species. $J$ Virol 86: 4370-4379. doi:10.1128/JVI.06959-11

Garrett D, Montesso F, Fougerolle S, Lopez-Alvarez MR Birand I, De Bock M, Huang CM, Legrand L, Pronost S, Paillot R. 2017. Refinement of the equine influenza model in the natural host: a meta-analysis to determine the benefits of individual nebulisation for experimental infection and vaccine evaluation in the face of decreased strain pathogenicity. Vet Microbiol 211: 150-159. doi:10.1016/ j.vetmic.2017.10.010

Gerber H. 1970. Clinical features, sequelae, and epidemiology of equine influenza. In Equine infectious diseases II (eds. Bryans JT, Gerber H), pp. 63-80. Karger, Basel.

Gilkerson JR. 2011. Equine influenza in Australia: a clinical overview. Aust Vet J 89(Suppl 1): 11-13. doi:10.1111/j .1751-0813.2011.00725.x

Gorman OT, Bean WJ, Kawaoka Y, Webster RG. 1990a. Evolution of the nucleoprotein gene of influenza A virus J Virol 64: 1487-1497. doi:10.1128/JVI.64.4.1487-1497 .1990

Gorman OT, Donis RO, Kawaoka Y, Webster RG. 1990b. Evolution of influenza A virus PB2 genes: implications for evolution of the ribonucleoprotein complex and origin of human influenza A virus. J Virol 64: 4893-4902. doi:10 $.1128 /$ JVI.64.10.4893-4902.1990

Gross DK, Hinchcliff KW, French PS, Goclan SA, Lahmers KK, Lauderdale M, Ellis JA, Haines DM, Slemons RD, Morley PS. 1998. Effect of moderate exercise on the severity of clinical signs associated with influenza virus infection in horses. Equine Vet J 30: 489-497. doi:10.1111/j .2042-3306.1998.tb04524.x

Guo Y, Wang M, Kawaoka Y, Gorman O, Ito T, Saito T, Webster RG. 1992. Characterization of a new avian-like influenza A virus from horses in China. Virology 188: 245-255. doi:10.1016/0042-6822(92)90754-D

Guo YJ, Wang M, Zheng G-S, Li W, Kawaoka Y, Webster RG. 1994. Characterisation of an equine influenza virus responsible for an outbreak in 1993 in China. In Equine Infectious Diseases VII: Proceedings of the Seventh International Conference, pp. 309-400. Newmarket, R\&W Publications, Tokyo.

Guo Y, Wang M, Zheng GS, Li W, Kawaoka Y, Webster RG. 1995. Seroepidemiological and molecular evidence for the presence of two H3N8 equine influenza viruses in China in 1993-94. J Gen Virol 76: 2009-2014. doi:10.1099/00221317-76-8-2009

Hannant D, Mumford JA, Jessett DM. 1988. Duration of circulating antibody and immunity following infection with equine influenza virus. Vet Rec 122: 125-128. doi:10.1136/vr.122.6.125

Happold J, Rubira R. 2011. Equine influenza: patterns of disease and seroprevalence in thoroughbred studs and implications for vaccination. Aust Vet J 89: 135-137. doi:10.1111/j.1751-0813.2011.00735.x

Hughes J, Allen RC, Baguelin M, Hampson K, Baillie GJ, Elton D, Newton JR, Kellam P, Wood JL, Holmes EC, et al. 2012. Transmission of equine influenza virus during an outbreak is characterized by frequent mixed infections and loose transmission bottlenecks. PLoS Pathog 8: e1003081. doi:10.1371/journal.ppat.1003081

Hurt AC, Vijaykrishna D, Butler J, Baas C, Maurer-Stroh S, Silva-de-la-Fuente MC, Medina-Vogel G, Olsen B, Kelso A, Barr IG, et al. 2014. Detection of evolutionarily distinct avian influenza A viruses in Antarctica. MBio 5: e0109801014.

Ismail TM, Sami AM, Youssef HM, Abou Zaid AA. 1990. An outbreak of equine influenza type 1 in Egypt in 1989. Vet Med J Giza 38: 195-206.

Ito T, Gorman OT, Kawaoka Y, Bean WJ, Webster RG. 1991. Evolutionary analysis of the influenza A virus M gene with comparison of the M1 and M2 proteins. J Virol 65: 54915498. doi:10.1128/JVI.65.10.5491-5498.1991

Ito T, Kawaoka Y, Ohira M, Takakuwa H, Yasuda J, Kida H, Otsuki K. 1999. Replacement of internal protein genes, with the exception of the matrix, in equine 1 viruses by equine 2 influenza virus genes during evolution in nature. $J$ Vet Med Sci 61: 987-989. doi:10.1292/jvms.61.987

Judson A. 1874. Report on the origin and progress of the epizootic among horses in 1872, with a table of mortality in New York. Third annual report of the Board of Health of the Health Department of the City of New York April 11, 1872 to April 30, 1873 (ed. York Board of Health of the City of New York), Vol. 47, pp. 492-521. D Appleton, New York.

Kasel JA, Couch RB. 1969. Experimental infection in man and horses with influenza A viruses. Bull World Health Organ 41: 447-452.

Kästner SB, Haines DM, Archer J, Townsend HG. 1999 Investigations on the ability of clenbuterol hydrochloride to reduce clinical signs and inflammation associated with equine influenza A infection. Equine Vet J 31: 160-168. doi:10.1111/j.2042-3306.1999.tb03810.x

Kawaoka Y, Bean WJ, Webster RG. 1989a. Evolution of the hemagglutinin of equine $\mathrm{H} 3$ influenza viruses. Virology 169: 283-292. doi:10.1016/0042-6822(89)90153-0

Kawaoka Y, Krauss S, Webster RG. 1989b. Avian-to-human transmission of the PB1 gene of influenza A viruses in the 1957 and 1968 pandemics. J Virol 63: 4603-4608. doi:10 .1128/JVI.63.11.4603-4608.1989

Khurelbaatar N, Krueger WS, Heil GL, Darmaa B, Ulziimaa D, Tserennorov D, Baterdene A, Anderson BD, Gray GC 2014. Little evidence of avian or equine influenza virus infection among a cohort of Mongolian adults with animal exposures, 2010-2011. PLoS One 9: e85616. doi:10 .1371/journal.pone.0085616

Koelle K, Khatri P, Kamradt M, Kepler TB. 2010. A twotiered model for simulating the ecological and evolutionary dynamics of rapidly evolving viruses, with an application to influenza. J R Soc Interface 7: 1257-1274. doi:10.1098/rsif.2010.0007 
Kumar N, Bera BC, Greenbaum BD, Bhatia S, Sood R, Selvaraj P, Anand T, Tripathi BN, Virmani N. 2016. Revelation of influencing factors in overall codon usage bias of equine influenza viruses. PLoS One 11: e0154376. doi:10 .1371/journal.pone.0154376

Lai AC, Chambers TM, Holland RE Jr, Morley PS, Haines DM, Townsend HG, Barrandeguy M. 2001. Diverged evolution of recent equine- 2 influenza $(\mathrm{H} 3 \mathrm{~N} 8)$ viruses in the Western Hemisphere. Arch Virol 146: 1063-1074. doi:10 $.1007 / \mathrm{s} 007050170106$

Landolt GA, Townsend HGG, Lunn DP. 2014. Equine influenza infection. In Equine infectious diseases (eds. Sellon DC, Long MT), pp. 141-151. Saunders, St. Louis.

Larson KR, Heil GL, Chambers TM, Capuano A, White SK, Gray GC. 2015. Serological evidence of equine influenza infections among persons with horse exposure, Iowa. $J$ Clin Virol 67: 78-83. doi:10.1016/j.jcv.2015.04.009

Legrand LJ, Pitel P, Marcillaud-Pitel CJ, Cullinane AA, Couroucé AM, Fortier GD, Freymuth FL, Pronost SL. 2013. Surveillance of equine influenza viruses through the RESPE network in France from November 2005 to October 2010. Equine Vet J 45: 776-783. doi:10.1111/evj .12100

Lewis NS, Daly JM, Russell CA, Horton DL, Skepner E, Bryant NA, Burke DF, Rash AS, Wood JL, Chambers TM, et al. 2011. Antigenic and genetic evolution of equine influenza A (H3N8) virus from 1968 to 2007. J Virol 85: 12742-12749. doi:10.1128/JVI.05319-11

Lin C, Holland RE Jr, Williams NM, Chambers TM. 2001. Cultures of equine respiratory epithelial cells and organ explants as tools for the study of equine influenza virus infection. Arch Virol 146: 2239-2247. doi:10.1007/ s007050170034

Liu KK. 1993. Report of an equine influenza outbreak which occurred in Hong Kong. Bull Office Intl Epizooties 105: 116-117.

Livesay GJ, O'Neill T, Hannant D, Yadav MP, Mumford JA. 1993. The outbreak of equine influenza (H3N8) in the United Kingdom in 1989: diagnostic use of an antigen capture ELISA. Vet Rec 133: 515-519. doi:10.1136/vr .133 .21 .515

Manuguerra JC, Zientara S, Sailleau C, Rousseaux C, Gicquel B, Rijks I, van der Werf S. 2000. Evidence for evolutionary stasis and genetic drift by genetic analysis of two equine influenza $\mathrm{H} 3$ viruses isolated in France. Vet Microbiol 74: 59-70. doi:10.1016/S0378-1135(00)00166-8

Masurel N, Mulder J. 1966. Studies on the content of antibodies for equine influenza viruses in human sera. Bull World Health Organ 34: 885-893.

Miller WC. 1966. Observations on the epizootiology of equine influenza. In First International Conference on Equine Infectious Diseases (ed. Bryans JT), pp. 141-144. Grayson Foundation, Lexington, KY.

Miño S, Mojsiejczuk L, Guo W, Zhang H, Qi T, Du C, Zhang X, Wang J, Campos R, Wang X. 2019. Equine influenza virus in Asia: phylogeographic pattern and molecular features reveal circulation of an autochthonous lineage. $J$ Virol 93: e00116-19. doi:10.1128/JVI.00116-19

Minuse E, McQueen JL, Davenport FM, Francis T Jr. 1965. Studies of antibodies to 1956 and 1963 equine influenza viruses in horses and man. J Immunol 94: 563-566.
Morens DM, Taubenberger JK. 2010a. An avian outbreak associated with panzootic equine influenza in 1872: an early example of highly pathogenic avian influenza? Influenza Other Respir Viruses 4: 373-377. doi:10.1111/j .1750-2659.2010.00181.x

Morens DM, Taubenberger JK. 2010b. Historical thoughts on influenza viral ecosystems, or behold a pale horse, dead dogs, failing fowl, and sick swine. Influenza Other Respir Viruses 4: 327-337. doi:10.1111/j.1750-2659.2010 $.00148 . \mathrm{x}$

Morley P. 2004. Viral respiratory disease in athletic horses. In Equine sports medicine and surgery: basic and clinical sciences of the equine athlete (eds. Hinchcliff KW, Kaneps AJ, Geor RJ), pp. 657-673. Saunders, Elsevier Sciences, London.

Morley PS, Townsend HG, Bogdan JR, Haines DM. 2000. Descriptive epidemiologic study of disease associated with influenza virus infections during three epidemics in horses. J Am Vet Med Assoc 216: 535-544. doi:10 $.2460 /$ javma.2000.216.535

Mumford JA. 1990. The diagnosis and control of equine influenza. Proc Am Assoc Equine Practit 36: 377-385.

Mumford JA, Hannant D, Jessett DM. 1990. Experimental infection of ponies with equine influenza (H3N8) viruses by intranasal inoculation or exposure to aerosols. Equine Vet J 22: 93-98. doi:10.1111/j.2042-3306.1990.tb04217.x

Muranaka M, Yamanaka T, Katayama Y, Niwa H, Oku K, Matsumura T, Oyamada T. 2012. Time-related pathological changes in horses experimentally inoculated with equine influenza A virus. J Equine Sci 23: 17-26. doi:10 $.1294 /$ jes.23.17

Murcia PR, Wood JL, Holmes EC. 2011. Genome-scale evolution and phylodynamics of equine H3N8 influenza A virus. J Virol 85: 5312-5322. doi:10.1128/JVI.02619-10

Murcia PR, Baillie GJ, Stack JC, Jervis C, Elton D, Mumford JA, Daly J, Kellam P, Grenfell BT, Holmes EC, et al. 2013 Evolution of equine influenza virus in vaccinated horses. J Virol 87: 4768-4771. doi:10.1128/JVI.03379-12

Nakajima K, Nobusawa E, Ogawa T, Nakajima S. 1990. Evolution of the NS genes of the influenza A viruses. I. The genetic relatedness of the NS genes of animal influenza viruses. Virus Genes 4: 5-13. doi:10.1007/BF00308561

Nedland H, Wollman J, Sreenivasan C, Quast M, Singrey A, Fawcett L, Christopher-Hennings J, Nelson E, Kaushik RS, Wang D, et al. 2018. Serological evidence for the cocirculation of two lineages of influenza D viruses in equine populations of the Midwest United States. Zoonoses Public Health 65: e148-e154. doi:10.1111/zph.12423

Newton JR, Mumford JA. 2005. Equine influenza. Oxford University Press, Oxford.

Newton JR, Verheyen K, Wood JL, Yates PJ, Mumford JA. 1999. Equine influenza in the United Kingdom in 1998. Vet Rec 145: 449-452. doi:10.1136/vr.145.16.449

Newton JR, Townsend HG, Wood JL, Sinclair R, Hannant D, Mumford JA. 2000. Immunity to equine influenza: relationship of vaccine-induced antibody in young thoroughbred racehorses to protection against field infection with influenza A/equine-2 viruses (H3N8). Equine Vet J 32: 65-74. doi:10.2746/042516400777612116

Newton JR, Daly JM, Spencer L, Mumford JA. 2006. Description of the outbreak of equine influenza (H3N8) in the United Kingdom in 2003, during which recently 
T.M. Chambers

vaccinated horses in Newmarket developed respiratory disease. Vet Rec 158: 185-192. doi:10.1136/vr.158.6.185

Nyaga PN, Wiggins AD, Priester WA. 1980. Epidemiology of equine influenza, risk by age, breed and sex. Comp Immunol Microbiol Infect Dis 3: 67-73. doi:10.1016/01479571(80)90040-5

Okazaki K, Kawaoka Y, Webster RG. 1989. Evolutionary pathways of the PA genes of influenza A viruses. Virology 172: 601-608. doi:10.1016/0042-6822(89)90202-X

O’Niell FD, Issel CJ, Henk WG. 1984. Electron microscopy of equine respiratory viruses in organ cultures of equine fetal respiratory tract epithelium. Am J Vet Res 45: 19531960.

Paillot R. 2014. A systematic review of recent advances in equine influenza vaccination. Vaccines (Basel) 2: $797-$ 831. doi:10.3390/vaccines 2040797

Park AW, Wood JL, Newton JR, Daly J, Mumford JA, Grenfell BT. 2003. Optimising vaccination strategies in equine influenza. Vaccine 21: 2862-2870. doi:10.1016/S0264410X(03)00156-7

Park AW, Daly JM, Lewis NS, Smith DJ, Wood JL, Grenfell BT. 2009. Quantifying the impact of immune escape on transmission dynamics of influenza. Science 326: 726728. doi:10.1126/science. 1175980

Patrono LV, Bonfante F, Zanardello C, Terregino C, Capua I, Murcia PR. 2015. Phylogenetically distinct equine influenza viruses show different tropism for the swine respiratory tract. J Gen Virol 96: 969-974. doi:10.1099/vir.0 .000049

Pavulraj S, Bera BC, Joshi A, Anand T, Virmani M, Vaid RK, Shanmugasundaram K, Gulati BR, Rajukumar K, Singh $\mathrm{R}$, et al. 2015. Pathology of equine influenza virus (H3N8) in murine model. PLoS ONE 10: e0143094. doi:10.1371/ journal.pone.0143094

Peek SF, Landolt G, Karasin AI, Slack J, Steinberg H, Semrad SD, Olsen CW. 2004. Acute respiratory distress syndrome and fatal interstitial pneumonia associated with equine influenza in a neonatal foal. $J$ Vet Intern Med 18: 132134. doi:10.1111/j.1939-1676.2004.tb00149.x

Powell DG, Watkins KL, Li PH, Shortridge KF. 1995. Outbreak of equine influenza among horses in Hong Kong during 1992. Vet Rec 136: 531-536. doi:10.1136/vr.136.21 .531

Pu J, Liu QF, Xia YJ, Fan YL, Brown EG, Tian FL, Liu JH. 2009. Genetic analysis of H3 subtype influenza viruses isolated from domestic ducks in northern China during 2004-2005. Virus Genes 38: 136-142. doi:10.1007/ s11262-008-0300-7

Quinlivan M, Zamarin D, Garcia-Sastre A, Cullinane A, Chambers T, Palese P. 2005. Attenuation of equine influenza viruses through truncations of the NS1 protein. J Virol 79: 8431-8439. doi:10.1128/JVI.79.13.8431-8439.2005

Quintana AM, Hussey SB, Burr EC, Pecoraro HL, Annis KM, Rao S, Landolt GA. 2011. Evaluation of infectivity of a canine lineage H3N8 influenza A virus in ponies and in primary equine respiratory epithelial cells. Am J Vet Res 72: 1071-1078. doi:10.2460/ajvr.72.8.1071

Rash A, Woodward A, Bryant N, McCauley J, Elton D. 2014 An efficient genome sequencing method for equine influenza [H3N8] virus reveals a new polymorphism in the PA-X protein. Virol J 11: 159. doi:10.1186/1743422X-11-159
Read AJ, Finlaison DS, Gu X, Davis RJ, Arzey KE, Kirkland PD. 2011. Application of real-time PCR and ELISA assays for equine influenza virus to determine the duration of viral RNA shedding and onset of antibody response in naturally infected horses. Aust Vet $J$ 89: 42-43. doi:10 $.1111 /$ j.1751-0813.2011.00740.x

Rodriguez L, Reedy S, Nogales A, Murcia PR, Chambers TM, Martinez-Sobrido L. 2018. Development of a novel equine influenza virus live-attenuated vaccine. Virology 516: 76-85. doi:10.1016/j.virol.2018.01.005

Ryan M, Gildea S, Walsh C, Cullinane A. 2015. The impact of different equine influenza vaccine products and other factors on equine influenza antibody levels in thoroughbred racehorses. Equine Vet J 47: 662-666. doi:10.1111/ evj.12353

Sack A, Daramragchaa U, Chuluunbaatar M, Gonchigoo B, Bazartseren B, Tsogbadrakh N, Gray GC. 2017. Low prevalence of enzootic equine influenza virus among horses in Mongolia. Pathogens 6: 61. doi:10.3390/patho gens6040061

Saenz RA, Quinlivan M, Elton D, Macrae S, Blunden AS, Mumford JA, Daly JM, Digard P, Cullinane A, Grenfell BT, et al. 2010. Dynamics of influenza virus infection and pathology. J Virol 84: 3974-3983. doi:10.1128/JVI .02078-09

Saito T, Kawaoka Y, Webster RG. 1993. Phylogenetic analysis of the N8 neuraminidase gene of influenza A viruses. Virology 193: 868-876. doi:10.1006/viro.1993.1196

Samper JC, Tibary A. 2006. Disease transmission in horses. Theriogenology 66: 551-559. doi:10.1016/j.theriogenology .2006 .04 .019

Sarasola P, Taylor DJ, Love S, McKellar QA. 1992. Secondary bacterial infections following an outbreak of equine influenza. Vet Rec 131: 441-442. doi:10.1136/vr.131.19.441

Schild GC, Stuart-Harris CH. 1965. Serological epidemiological studies with influenza A viruses. J Hyg (Lond) 63: 479-490.

Singh G. 1994. Characterization of A/eq-1 virus isolated during the equine influenza epidemic in India. Acta Virol 38: $25-26$.

Smith BP. 1979. Influenza in foals. J Am Vet Med Assoc 174: 289-290.

Solórzano A, Foni E, Córdoba L, Baratelli M, Razzuoli E, Bilato D, Martín del Burgo MA, Perlin DS, Martínez J, Martínez-Orellana P, et al. 2015. Cross-species infectivity of H3N8 influenza virus in an experimental infection in swine. J Virol 89: 11190-11202. doi:10.1128/JVI.01509-15

Sovinova O, Tumova B, Pouska F, Nemec J. 1958. Isolation of a virus causing respiratory disease in horses. Acta Virol 2: $52-61$.

Spackman E, McCracken KG, Winker K, Swayne DE. 2006. $\mathrm{H} 7 \mathrm{~N} 3$ avian influenza virus found in a South American wild duck is related to the Chilean 2002 poultry outbreak, contains genes from equine and North American wild bird lineages, and is adapted to domestic turkeys. J Virol 80: 7760-7764. doi:10.1128/JVI.00445-06

Su S, Wang L, Fu X, He S, Hong M, Zhou P, Lai A, Gray G, Li S. 2014. Equine influenza $A(H 3 N 8)$ virus infection in cats. Emerg Infect Dis 20: 2096-2099. 
Suzuki Y. 2005. Sialobiology of influenza: molecular mechanism of host range variation of influenza viruses. Biol Pharm Bull 28: 399-408. doi:10.1248/bpb.28.399

Suzuki Y, Ito T, Suzuki T, Holland RE Jr, Chambers TM, Kiso M, Ishida H, Kawaoka Y. 2000. Sialic acid species as a determinant of the host range of influenza A viruses. J Virol 74: 11825-11831. doi:10.1128/JVI.74.24.1182511831.2000

Takahashi T, Takano M, Kurebayashi Y, Masuda M, Kawagishi S, Takaguchi M, Yamanaka T, Minami A, Otsubo T, Ikeda K, et al. 2014. $N$-glycolylneuraminic acid on human epithelial cells prevents entry of influenza A viruses that possess $N$-glycolylneuraminic acid binding ability. J Virol 88: 8445-8456. doi:10.1128/JVI.00716-14

Tu J, Zhou H, Jiang T, Li C, Zhang A, Guo X, Zou W, Chen $\mathrm{H}$, Jin M. 2009. Isolation and molecular characterization of equine H3N8 influenza viruses from pigs in China. Arch Virol 154: 887-890. doi:10.1007/s00705-009-0381-1

Tumova B, Easterday BC, Stumpa A. 1972. Simultaneous occurrence of A-equi- 1 and A-equi- 2 influenza viruses in a small group of horses. Am J Epidemiol 95: 80-87.

Virmani N, Bera BC, Gulati BR, Karuppusamy S, Singh BK, Kumar Vaid R, Kumar S, Kumar R, Malik P, Khurana SK, et al. 2010. Descriptive epidemiology of equine influenza in India (2008-2009): temporal and spatial trends. Vet Ital 46: 449-458.

Waddell GH, Teigland MB, Sigel MM. 1963. A new influenza virus associated with equine respiratory disease. J Am Vet Med Assoc 143: 587-590.

* Wasik BR, Voorhees IEH, Parrish CR. 2020. Canine and feline influenza. Cold Spring Harb Perspect Med a038562. doi:10.1101/cshperspect.a038562.

Webster RG. 1993. Are equine 1 influenza viruses still present in horses? Equine Vet J 25: 537-538. doi:10.1111/j 2042-3306.1993.tb03009.x

Webster RG, Guo YJ. 1991. New influenza virus in horses. Nature 351: 527. doi:10.1038/351527a0

Webster RG, Thomas TL. 1993. Efficacy of equine influenza vaccines for protection against A/Equine/Jilin/89 (H3N8) - a new equine influenza virus. Vaccine 11: 987-993. doi:10.1016/0264-410X(93)90122-E

Willoughby R, Ecker G, McKee S, Riddolls L, Vernaillen C, Dubovi E, Lein D, Mahony JB, Chernesky M, Nagy E, et al. 1992. The effects of equine rhinovirus, influenza virus and herpesvirus infection on tracheal clearance rate in horses. Can J Vet Res 56: 115-121.

Wilson WD. 1993. Equine influenza. Vet Clin North Am Equine Pract 9: 257-282. doi:10.1016/S0749-0739(17) 30395-4

Woodward AL, Rash AS, Blinman D, Bowman S, Chambers TM, Daly JM, Damiani A, Joseph S, Lewis N, McCauley JW, et al. 2014. Development of a surveillance scheme for equine influenza in the $\mathrm{UK}$ and characterisation of viruses isolated in Europe, Dubai and the USA from 2010-2012. Vet Microbiol 169: 113-127. doi:10.1016/j.vetmic.2013 .11 .039

Worobey M, Han GZ, Rambaut A. 2014. A synchronized global sweep of the internal genes of modern avian influenza virus. Nature 508: 254-257. doi:10.1038/na ture 13016

Xie T, Anderson BD, Daramragchaa U, Chuluunbaatar M, Gray GC. 2016. A review of evidence that equine influenza viruses are zoonotic. Pathogens 5: E50.

Yamanaka T, Tsujimura K, Kondo T, Matsumura T, Ishida H, Kiso M, Hidari KI, Suzuki T. 2010. Infectivity and pathogenicity of canine H3N8 influenza A virus in horses. Influenza Other Respir Viruses 4: 345-351. doi:10.1111/j .1750-2659.2010.00157.x

Yondon M, Heil GL, Burks JP, Zayat B, Waltzek TB, Jamiyan B-O, McKenzie PP, Krueger WS, Friary JA, Gray GC. 2013. Isolation and characterization of H3N8 equine influenza A virus associated with the 2011 epizootic in Mongolia. Influenza Other Respir Viruses 7: 659-665. doi:10.1111/irv.12069

Yondon M, Zayat B, Nelson MI, Heil GL, Anderson BD, Lin X, Halpin RA, McKenzie PP, White SK, Wentworth DE, et al. 2014. Equine influenza A(H3N8) virus isolated from Bactrian camel, Mongolia. Emerg Infect Dis 20: 2144 2147. doi:10.3201/eid2012.140435

Zhu H, Damdinjav B, Gonzalez G, Patrono LV, RamirezMendoza H, Amat JAR, Crispell J, Parr YA, Hammond TA, Shiilegdamba E, et al. 2019. Absence of adaptive evolution is the main barrier against influenza emergence in horses in Asia despite frequent virus interspecies transmission from wild birds. PLoS Pathog 15: e1007531. doi:10.1371/journal.ppat.1007531 


\section{$\&_{\mathrm{CSH}}^{\infty} \&$ Cold Spring Harbor

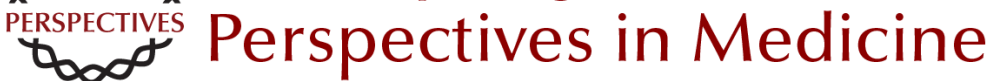

\section{Equine Influenza}

Thomas M. Chambers

Cold Spring Harb Perspect Med 2022; doi: 10.1101/cshperspect.a038331 originally published online March 9, 2020

\section{Subject Collection Influenza: The Cutting Edge}

\section{Emerging HxNy Influenza A Viruses William J. Liu, Yan Wu, Yuhai Bi, et al. \\ Equine Influenza Thomas M. Chambers \\ Human Influenza Epidemiology Sukhyun Ryu and Benjamin J. Cowling}

Host Cell Factors That Interact with Influenza Virus Ribonucleoproteins Ecco Staller and Wendy S. Barclay Induction and Evasion of Type-I Interferon Responses during Influenza A Virus Infection Raquel Muñoz-Moreno, Carles Martínez-Romero and Adolfo García-Sastre

Structure and Function of Influenza Polymerase Joanna M. Wandzik, Tomas Kouba and Stephen Cusack

H7N9 Influenza Virus in China Chengjun Li and Hualan Chen

\section{H5 Influenza Viruses in Egypt} Rabeh El-Shesheny, Ahmed Kandeil, Ahmed Mostafa, et al.

\author{
Antivirals Targeting the Neuraminidase \\ Larisa Gubareva and Teena Mohan \\ Accessory Gene Products of Influenza A Virus \\ Rute M. Pinto, Samantha Lycett, Eleanor Gaunt, et \\ al. \\ Influenza Immunization in the Context of \\ Preexisting Immunity \\ Susanne L. Linderman, Ali H. Ellebedy, Carl Davis, \\ et al. \\ Hemagglutinin Structure and Activities \\ Steven J. Gamblin, Sébastien G. Vachieri, Xiaoli \\ Xiong, et al. \\ Live Attenuated Cold-Adapted Influenza Vaccines \\ Kanta Subbarao \\ Next-Generation Influenza Vaccines \\ Masaru Kanekiyo and Barney S. Graham
Selective Genome Packaging Mechanisms of Influenza A Viruses Takeshi Noda \\ Systems Biological Analysis of Immune Response \\ to Influenza Vaccination \\ Mario Cortese, Amy C. Sherman, Nadine G. \\ Rouphael, et al.
}

For additional articles in this collection, see http://perspectivesinmedicine.cshlp.org/cgi/collection/ 